\section{Relacionalidade como condição necessária da identidade humana: perspectiva crítica de bioética}

\section{Silva, Maria Emilia de Oliveira Schpallir Doutora em Bioética pelo Centro Universitário São Camilo $(S P)$, especialista em Coloproctologia pela $S B C P$, especialista em Bioética pela Faculdade de Medicina da USP, graduada em Teologia pela PUC-Campinas, membro da Comissão de Bioética da CNBB, médica, Brasil. emiliaschpallir@hotmail.com}

\section{Anjos, Márcio Fabri dos \\ Doutor em Teologia, professor no ITESP, São Paulo, coordenador do programa de doutorado em Bioética no *C.Univ. São Camilo; secretário da Sociedade Brasileira de Bioética; membro da Câmara de Bioética do Conselho de Medicina do Estado de S. Paulo. Brasil.}

PALAVRAS-CHAVE: relacionalidade, bioética, responsabilidade, identidade humana.

Introdução: Somos seres relacionais e, como tal, interdependentes. Nascemos e sobrevivemos através de relações, de onde decorrem exigências éticas. O conceito de relacionalidade será aqui entendido como a condição humana de interagir com o outro, identificando-o como um semelhante; portanto diz respeito à alteridade e engloba necessariamente a empatia. $\mathrm{O}$ trabalho propõe-se, explorando as teorias da epigenética, a avaliar o alcance da natureza biológica do ser humano como ser relacional, e a relacionalidade como condição necessária para a conservação da identidade humana. Método: Consiste em estudo bibliográfico hermenêutico argumentativo em torno da concepção de Maturana acerca da identidade humana com os decorrentes desdobramentos para a reflexão bioética norteada pelo princípio da responsabilidade. Resultados: Maturana tem por campo de pesquisa a neurobiologia. A partir de seus estudos sobre a organização dos seres vivos como sistemas autônomos e a descrição do sistema nervoso como sistema fechado, começa a desenvolver a Biologia do Conhecimento e a Biologia do Amor. Com a obra $A$ árvore do conhecimento: as bases biológicas da compreensão humana, apresenta uma reflexão a partir das ciências da vida, entrelaçadas com as ciências humanas e sociais, oferecendo uma nova alternativa para se pensar a condição humana. ${ }^{1}$ Maturana trabalha com o entendimento do ser humano como ser sistêmico, ou seja, a identidade humana é um fenômeno sistêmico relacional, epigenético, e não um fenômeno genético e, como tal, perder-se-á se deixarmos de viver e conservar o viver no que ele denomina biologia do amor e da intimidade. A biologia do amor é o que nos constitui e realiza como seres humanos. ${ }^{2,3,4,5} \mathrm{~A}$ epigenética refere-se a alterações na expressão dos genes dependente de fatores ambientais, sem alteração na sequência gênica, produzindo fenótipos distintos. A alteração fenotípica pode ser transferida para uma ou mais gerações. ${ }^{5} \mathrm{~A}$ reflexão de Maturana parte de uma episteme experimental e biologicista da identidade humana, que fundamenta toda uma reflexão ética sobre o ser humano. Alerta para o risco que a humanidade corre de perder sua identidade e, anulando sua humanidade, ser substituída por uma nova linhagem. Fundamenta seus argumentos cientificamente, na epigenética, apontando aspectos do comportamento humano que são pontos de esperança e invoca uma reflexão ética na linha da responsabilidade. A originalidade de sua reflexão está exatamente nessa epistemologia que permite uma fundamentação empírica, biológica, para justificar a relacionalidade como constitutiva e essencial na identidade humana. Nesta perspectiva, o caminho que escolhermos, as nossas atitudes, revestem-se de grande responsabilidade, porque implicarão na manutenção ou perda dessa identidade, uma vez que ela não é genética, estática, mas dependente de um fenômeno epigenético. Conclusão: Conclui-se que a relacionalidade é constitutiva e essencial na identidade humana. A percepção de que nossas atitudes podem comprometer essa identidade aumenta a nossa responsabilidade para com nossos atos e tomada de decisões e, portanto, diz respeito diretamente ao campo da ética. Quando a alteridade é substituída pela dinâmica do poder, há um comprometimento da relacionalidade. A identidade humana, centrada na biologia do amor, na cooperação, é substituída pela dinâmica sujeição/dominação, correndo o risco de perder-se.

\section{REFERÊNCIAS}

[1] SCHLICHTING, H. A.. A biologia do amor e a biologia do conhecimento de Humberto Maturana: contribuição à formação de professores e à educação ambiental. 2007. 133p. Dissertação de Mestrado em Educação Universidade Federal de Santa Maria, RS, 2007.

[2] MATURANA, H.; VARELA, F. A árvore do conhecimento. As bases biológicas do entendimento humano. São Paulo: Workshopsy - Livraria, Editora e Promotora de Eventos, 1995, 281p.

[3] MATURANA, H. El sentido de lo humano. $8^{\mathrm{a}}$ ed. Chile: Domen Ediciones, 1996. 315p.

[4] MATURANA, H; REZEPKA, S. N. Formação humana e capacitação. $2^{\mathrm{a}}$ ed. Rio de Janeiro: Vozes, 2001. 86p.

[5] Silva, M.E.O.S. Autonomia e relacionalidade na ética da reprodução humana: perspectivas críticas de bioética. 2017. 264f. Tese (Doutorado em Bioética) - Centro Universitário São Camilo, São Paulo, 2017a. 